\title{
DEPRESSANT EFFECTS OF HIGH CONCENTRATIONS OF INSPIRED OXYGEN ON ERYTHROCYTOGENESIS. OBSERVATIONS ON \\ PATIENTS WITH SICKLE CELL ANEMIA WITH A DESCRIPTION OF THE OBSERVED TOXIC MANIFESTATIONS OF OXYGEN ${ }^{1,2}$
}

\author{
By EDWARD H. REINHARD, CARL V. MOORE, REUBENIA DUBACH, \\ AND LEO J. WADE \\ (From the Department of Internal Medicine, Washington University School of Medicine, St. Louis)
}

(Received for publication November 4, 1943)

This report describes the effect of the continuous inhalation of 70 to 100 per cent oxygen for 8 to 20 days on the cellular elements of the blood of patients with sickle cell anemia. The investigation was originally begun in an effort to reduce the degree of intravascular sickling of red blood cells. There were two reasons for trying to produce this result: (1) Diggs (1) and Bauer (2) have suggested that the pain of sickle cell crises may result from anoxia of tissues caused by occlusion of blood vessels with elongated clumped cells, and (2) the increased rate of hemolysis in sickle cell anemia might possibly be due to the greater trauma to which sickled cells are subjected during circulation. Therefore, if the abnormal shape could be corrected, the pain of crises might be relieved, the rate of hemolysis decreased, and the degree of anemia lessened. It is well known that in vitro the erythrocytes of patients with sickle cell anemia will become biconcave discs when they are exposed to air or oxygen, and become sickled when they are exposed to carbon dioxide $(3,4)$. Sherman (4), furthermore, demonstrated that there are fewer sickled cells in arterial than in venous blood. But, when this study was begun, no one had shown that the oxygen tension of arterial blood could be increased sufficiently to influence the degree of intravascular sickling. That this result might be accomplished, however, seemed likely since (1) Boothby, Lovelace, and Uihlein (5) were able to increase alveolar oxygen tension to more than $500 \mathrm{~mm} . \mathrm{Hg}$, and (2) Behnke (6)

\footnotetext{
1 This work was aided by grants from Mr. Edward Mallinckrodt, Jr. and from the Markle Foundation.

2 Presented in part at the 15th Annual Meeting of the Central Society for Clinical Research, Chicago, November 6, 1942.
}

had shown that the oxygen tension of arterial blood approximates that in the alveoli.

Oxygen was administered for periods of 8 to 20 days on 6 different occasions to 4 patients with sickle cell anemia. Early in the study it became obvious that the degree of intravascular sickling was diminished during the periods of oxygen inhalation, but there was no evidence that the rate of hemolysis or the occurrence of pain was affected. However, there were definite indications that erythrocytogenesis was depressed. On the fourth to sixth day of oxygen administration, the reticulocyte level began to fall, and several days later the red blood cells also began to decrease in number. During 3 of the 6 periods, the red cell counts fell by more than $1,000,000$ cells. Four or 5 days after the administration of oxygen was discontinued, a pronounced reticulocytosis developed and the number of red cells returned to approximately the pre-oxygen level. Congestion of the mucous membrane of the upper respiratory passages, anorexia, and nausea were the principal evidences of toxic effects produced by the high concentrations of oxygen.

\section{Methods and experimental conditions}

Red and white blood cell counts were made with pipettes and hemocytometer chambers that had been standardized by the United States Bureau of Standards. Hemoglobin determinations were made by the oxyhemoglobin method of Evelyn (7). Differential leukocyte counts were made on supravital preparations. Platelets were estimated by Dameshek's technic (8). Both wet and dry preparations were used for counting reticulocytes. Wet and fixed films were used in applying Sherman's method for the determination of the percentage of sickled cells (4).

Changes in the rate of hemolysis were estimated from determinations of serum bilirubin, serum iron, and the excretion of urobilinogen and stercobilinogen. Quantita- 
tive estimation of the serum bilirubin was made with an Evelyn photoelectric colorimeter (9). Serum iron values were obtained with the thiocyanate technic (10). The method of Watson was used for measuring the excretion of urobilinogen and stercobilinogen (11). Urine and stool specimens were collected in 4-day periods.

The oxygen content of arterial and venous blood was determined on $1 \mathrm{ml}$. of blood by the method of Van Slyke and Neill (12a) as described in Peters' and Van Slyke's Quantitative Clinical Chemistry, Methods (12b). The $\mathrm{CO}_{2}$ and $\mathrm{O}_{2}$ were liberated from the blood by vacuum extraction with gas-free saponin-ferricyanide-lactic acid mixture and the pressure of the combined gases was read at $2 \mathrm{ml}$. volume in Van Slyke's manometric gas analysis apparatus; the $\mathrm{CO}_{2}$ was absorbed from the mixture with air-free and carbonate-free $\mathrm{N} \mathrm{NaOH}$ and the pressure was again taken at $2 \mathrm{ml}$; the oxygen was absorbed with freshly prepared alkaline hyposulfite solution and the pressure was again read at $2 \mathrm{ml}$. volume; finally the pressure of the residual nitrogen was read at $0.5 \mathrm{ml}$. volume. Several times during the study, alveolar air samples were collected by the method of Henderson and Morriss (13) and were analyzed for partial pressures of oxygen, nitrogen, and carbon dioxide (technic of Van Slyke and Sendroy) (14).

Oxygen was administered by means of a BoothbyLovelace-Bulbulian (B.L.B.) mask (5). A nasal mask was worn continuously during the day, even at meal-times. At night, the oronasal mask was substituted so that patients who opened their mouths during sleep would not breath air. One of the subjects (B.W.) did not tolerate the face mask well; she was permitted to wear the nasal mask day and night. Repeated observations revealed that she did not sleep with her mouth open. In all cases, the oxygen flow was kept at 7 to 8 liters per minute, and a humidifier was used. Control periods before and after the periods of oxygen administration varied from 4 days to a month or more.

Case reports describing the patients studied in this investigation are recorded at the end of the paper.

\section{Concentrations of alveolar oxygen obtained; degree of saturation of arterial and venous blood}

Boothby has shown that it is possible to maintain the alveolar oxygen at about 90 to 92 per cent with the B.L.B. inhalation apparatus when the rate of flow of oxygen is 7 to 8 liters per minute (5). This, he showed, corresponds to approximately 100 per cent oxygen in the inspired air. He also found that when the nasal mask is worn and the patient is permitted to eat or talk, the alveolar oxygen content falls to 65 per cent. The 4 determinations of alveolar oxygen content
TABLE I

Percentages of $\mathrm{O}_{2}, \mathrm{~N}_{2}$, and $\mathrm{CO}_{2}$ in alveolar air collected during periods of oxygen therapy

\begin{tabular}{|c|c|c|c|c|c|}
\hline \multirow{2}{*}{ Patient } & \multirow{2}{*}{ Date } & \multirow{2}{*}{ Oxygen therapy or control } & \multicolumn{3}{|c|}{ Alveolar gas } \\
\hline & & & $\mathrm{O}_{2}$ & $\mathrm{~N}_{2}$ & $\mathrm{CO}_{2}$ \\
\hline B. W. & $\begin{array}{l}7 / 17 / 42 \\
7 / 28 / 42 \\
7 / 29 / 42 \\
8 / 17 / 42 \\
1 / 19 / 43\end{array}$ & $\begin{array}{l}\text { 7th day of } \mathrm{O}_{2} \text { therapy } \\
18 \text { th day of } \mathrm{O}_{2} \text { therapy } \\
19 \text { th day of } \mathrm{O}_{2} \text { therapy } \\
17 \text { th day after } \mathrm{O}_{2} \text { was } \\
\text { discontinued } \\
12 \text { th day of } \mathrm{O}_{2} \text { therapy }\end{array}$ & $\begin{array}{r}\text { volu } \\
63.4 \\
90.6 \\
81.0 \\
16.8 \\
77.5\end{array}$ & $\begin{array}{c}\text { mes per } \\
31.4 \\
5.9 \\
13.6 \\
78.6\end{array}$ & $\begin{array}{l}\text { cent } \\
5.3 \\
3.6 \\
5.7 \\
4.5\end{array}$ \\
\hline
\end{tabular}

made in the present study during periods of oxygen administration gave values which varied from 63.4 to 90.6 per cent oxygen (Table I). These figures are roughly equivalent to levels of 70 to 100 per cent oxygen in the inspired gas mixture (15). The alveolar oxygen content unquestionably fell at meal-times and when the subjects talked; it is unlikely, however, that the percentage was often lower than 60 during the periods of oxygen administration.

Further evidence of the high oxygen tension produced in alveolar air was provided by the increased oxygen saturation observed in arterial and venous blood. Both the combined and dissolved oxygen of blood are dependent on the partial pressure of oxygen in the alveoli. Boothby has shown that the amount of oxygen in $100 \mathrm{ml}$. of arterial blood of the average normal individual can be increased from 19.5 to $22.2 \mathrm{ml}$. when 100 per cent oxygen is inhaled instead of air (16). This amounts to an increase of 10 to 15 per cent in the oxygen content of arterial blood and produces a definite change in the partial pressure of oxygen in both the capillaries and tissues (16). The results obtained in these 4 patients were similar to those reported by Boothby. Determinations of oxygen content and capacity of both arterial and venous blood were usually made at 4-day intervals. With few exceptions, while pure oxygen was breathed, the oxygen content of arterial blood was greater than the so-called "oxygen capacity" determined with room air and the oxygen saturation of venous blood was invariably raised. Data obtained on one of the patients and illustrative of the changes observed are recorded in Table II. 
TABLE II

Oxygen content, capacity, and saturation of venous and arterial blood of patient before, during, and after oxygen administration

Patient L. McC., colored female, age 25 years

\begin{tabular}{|c|c|c|c|c|c|c|}
\hline \multirow{2}{*}{ Date } & \multicolumn{3}{|c|}{ Arterial } & \multicolumn{3}{|c|}{ Venous } \\
\hline & $\begin{array}{l}\text { Con- } \\
\text { tent }\end{array}$ & $\begin{array}{l}\text { "Capac- } \\
\text { ity" }\end{array}$ & Sat. & $\begin{array}{l}\text { Con- } \\
\text { tent }\end{array}$ & $\begin{array}{l}\text { "Capac- } \\
\text { ity" }\end{array}$ & Sat. \\
\hline $\begin{array}{l}3 / 9 / 42 \\
3 / 18 / 42\end{array}$ & $\begin{array}{l}7.9 \\
9.2\end{array}$ & $\begin{array}{r}8.7 \\
10.3\end{array}$ & $\begin{array}{c}\text { per cent } \\
90.8 \\
89.3\end{array}$ & $\begin{array}{l}3.1 \\
3.1\end{array}$ & $\begin{array}{r}8.6 \\
10.3\end{array}$ & $\begin{array}{c}\text { per cent } \\
36.0 \\
30.1\end{array}$ \\
\hline $\begin{array}{l}3 / 18 / 42 \\
3 / 22 / 42 \\
3 / 30 / 42\end{array}$ & $\begin{array}{r}10.1 \\
8.4\end{array}$ & $\begin{array}{r}10.0 \\
8.0\end{array}$ & $\begin{array}{c}\text { oxygen } \\
101.0 \\
105.0\end{array}$ & $\begin{array}{c}\text { tarted } \\
6.3 \\
3.9\end{array}$ & $\begin{array}{r}10.0 \\
7.9\end{array}$ & $\begin{array}{l}63.0 \\
49.4\end{array}$ \\
\hline $\begin{array}{l}3 / 30 / 42 \\
4 / 3 / 42 \\
4 / 8 / 42 \\
4 / 20 / 42\end{array}$ & $\begin{array}{r}5.7 \\
7.5 \\
12.0\end{array}$ & $\begin{array}{r}6.9 \\
10.1 \\
14.2\end{array}$ & $\begin{array}{r}\text { oxygen } \\
82.6 \\
74.2 \\
84.5\end{array}$ & $\begin{array}{c}\text { oppec } \\
1.4 \\
2.9 \\
5.1\end{array}$ & $\begin{array}{r}6.9 \\
10.1 \\
14.2\end{array}$ & $\begin{array}{l}20.3 \\
28.7 \\
35.9\end{array}$ \\
\hline
\end{tabular}

Determinations made on $1 \mathrm{ml}$. samples of blood according to method described by Peters and Van Slyke (12b).

\section{Changes in the degree of sickling produced by oxygen administration}

When the percentage of sickled cells was estimated in samples of arterial and venous blood, considerable difficulty was experienced in deciding which cells should be called "sickled." The difficulty can easily be understood because, as Diggs has demonstrated, the abnormal cells show all degrees of sickling (17). There were, in the preparations made by Sherman's technic (4), many oblong and irregularly shaped red cells which were not truly sickled. Cells of this type are labeled "Ab" in Figure 1, while frankly sickled cells are marked by the letter "S." In order to compensate for some of this difficulty, counts during the last 4 periods of this study were done of both $(a)$ the total abnormal cells, and $(b)$ the true sickled cells. It was not possible to establish sharply defined rules governing each of these categories, and frequently there was considerable variation in the counts done by two different observers. The figures tabulated in Table III represent the average of values obtained each time by the same two persons when several thousand cells were counted.

From the data in Table III, it can be seen that there were more abnormal forms in venous than in arterial blood. This result is consistent with the fact that the oxygen tension of arterial blood is greater than that of venous blood. In most instances, during the time of oxygen administra- tion, the percentage of abnormal forms was less in both arterial and venous blood than during pre- and post-oxygen control periods, a finding which confirms the observation made by Klinefelter (18). The most definite change occurred when oxygen inhalation was discontinued; the percentage of sickled cells rose sharply and then gradually declined until basal levels for each subject were reached.

\section{Rate of hemolysis as influenced by oxygen administration}

Whenever the rate of hemolysis is accelerated, the excretion of urobilinogen and of stercobilinogen is increased, the icterus index and serum bilirubin become elevated, and the serum iron value rises (if erythrocytogenesis is unaltered) (19). These changes are reversed when the rate of hemolysis slows. Watson has presented evidence to show that variations in the excretion of urobilinogen and stercobilinogen constitute the

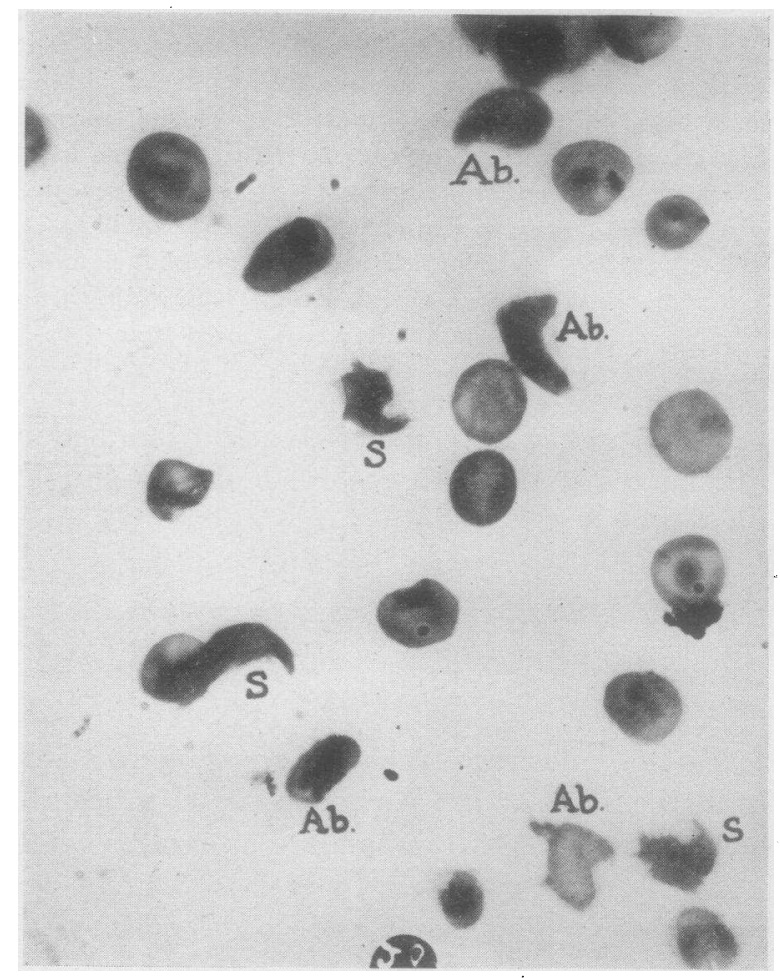

Fig. 1. Formalin Fixed Sickle Cell Preparation

In counting such a preparation, cells marked $\mathrm{S}$ were recorded as grossly sickled while cells marked $\mathrm{Ab}$. were recorded as abnormal. 
most sensitive known index of the rate of red blood cell destruction (20). Results pertaining to this excretion will, therefore, be presented first. In order to avoid unnecessary repetition, the term "urobilinogen excretion" will be used to designate excretion of both urobilinogen and stercobilinogen; both chromogens are determined by the method used.

Data on the excretion of urobilinogen of these 4 subjects are presented graphically in Figures 2

TABLE III

Percentage of abnormal erythrocytes in arterial and venous blood before, during, and after periods of oxygen administration

\begin{tabular}{|c|c|c|c|c|c|}
\hline \multirow[b]{2}{*}{ Patient } & \multirow[b]{2}{*}{ Date } & \multicolumn{2}{|c|}{ Arterial blood } & \multicolumn{2}{|c|}{ Venous blood } \\
\hline & & $\begin{array}{c}\text { Total } \\
\text { abnormal } \\
\text { count }\end{array}$ & $\begin{array}{c}\text { True } \\
\text { sickled } \\
\text { count }\end{array}$ & $\begin{array}{c}\text { Total } \\
\text { abnormal } \\
\text { count }\end{array}$ & $\begin{array}{c}\text { True } \\
\text { sickled } \\
\text { count }\end{array}$ \\
\hline G. C. & $\begin{array}{l}12 / 5 / 41 \\
12 / 8 / 41 \\
12 / 12 / 41 \\
12 / 12 / 41 \\
12 / 17 / 41 \\
12 / 19 / 41 \\
12 / 20 / 41 \\
12 / 20 / 41 \\
12 / 24 / 41\end{array}$ & $\begin{array}{c}\text { per cent } \\
14 \\
13 \\
24 \\
7 \\
7 \\
15 \\
23 \\
35\end{array}$ & $\begin{array}{l}\text { per cent } \\
\text { oxygen } \\
\text { oxygen }\end{array}$ & $\begin{array}{c}\text { per cent } \\
54 \\
30 \\
44 \\
\text { started } \\
27 \\
30 \\
30 \\
\text { stopped } \\
49\end{array}$ & per cent \\
\hline B. W. & $\begin{array}{r}12 / 30 / 41 \\
12 / 30 / 41 \\
1 / 3 / 42 \\
1 / 7 / 42 \\
1 / 7 / 42 \\
1 / 11 / 42\end{array}$ & $\begin{array}{l}19 \\
14 \\
21 \\
41\end{array}$ & $\begin{array}{l}\text { oxygen } \\
\text { oxygen }\end{array}$ & $\begin{array}{c}34 \\
\text { started } \\
17 \\
26 \\
\text { stopped } \\
50\end{array}$ & \\
\hline L. McC. & $\begin{array}{l}3 / 9 / 42 \\
3 / 18 / 42 \\
3 / 22 / 42 \\
3 / 26 / 42 \\
3 / 30 / 42 \\
3 / 30 / 42 \\
4 / 3 / 42 \\
4 / 8 / 42\end{array}$ & $\begin{array}{l}44 \\
20 \\
32 \\
33 \\
\\
45 \\
37\end{array}$ & $\begin{array}{c}4 \\
\text { oxygen } \\
5 \\
8 \\
6 \\
\text { oxygen } \\
16 \\
10\end{array}$ & $\begin{array}{c}47 \\
\text { started } \\
44 \\
34 \\
48 \\
\text { topped } \\
67 \\
52\end{array}$ & $\begin{array}{l}22 \\
17 \\
19 \\
29 \\
37 \\
30\end{array}$ \\
\hline L. McC. & $\begin{array}{l}4 / 20 / 42 \\
4 / 27 / 42 \\
4 / 27 / 42 \\
5 / 1 / 42 \\
5 / 5 / 42 \\
5 / 9 / 42 \\
5 / 13 / 42\end{array}$ & $\begin{array}{l}38 \\
42 \\
\\
25 \\
32 \\
37\end{array}$ & $\begin{array}{c}12 \\
16 \\
\text { oxygen } \\
8 \\
7 \\
\text { oxygen } \\
12\end{array}$ & $\begin{array}{c}61 \\
65 \\
\text { started } \\
46 \\
43 \\
\text { stopped } \\
47\end{array}$ & $\begin{array}{l}39 \\
41 \\
\\
19 \\
25 \\
\\
29\end{array}$ \\
\hline B. W. & $\begin{array}{l}7 / 10 / 42 \\
7 / 10 / 42 \\
7 / 14 / 42 \\
7 / 18 / 42 \\
7 / 23 / 42 \\
7 / 27 / 42 \\
7 / 30 / 42 \\
8 / 4 / 42 \\
8 / 7 / 42 \\
8 / 14 / 42\end{array}$ & $\begin{array}{l}38 \\
37 \\
35 \\
39 \\
34 \\
\\
54 \\
48 \\
34\end{array}$ & $\begin{array}{c}9 \\
\text { oxygen } \\
2 \\
3 \\
2 \\
2 \\
\text { oxygen } \\
5 \\
4 \\
2\end{array}$ & $\begin{array}{c}51 \\
\text { started } \\
47 \\
41 \\
56 \\
61 \\
\text { topped } \\
67 \\
76 \\
44\end{array}$ & $\begin{array}{l}23 \\
15 \\
20 \\
15 \\
17\end{array}$ \\
\hline
\end{tabular}

TABLE IV

Average total excretion of urobilinogen in urine and stool

\section{Patient}

G. C.

B. W.

L. McC.

\begin{tabular}{|c|c|}
\hline Control periods & Oxygen period \\
\hline \multicolumn{2}{|c|}{ mgm. per 24 hours } \\
\hline $\begin{array}{l}261 \\
755 \\
346\end{array}$ & $\begin{array}{l}139 \\
778 \\
331\end{array}$ \\
\hline
\end{tabular}

to 6. From these graphs, it is apparent that no consistent change was produced in the excretion of urobilinogen produced by oxygen administration. Furthermore, when the values for urobilinogen excretion were averaged for all oxygen and all control periods, the average figures again failed to demonstrate any consistent effect of oxygen administration on the excretion of urobilinogen (Table IV).

Values for the icterus index, serum bilirubin, and serum iron showed fluctuations which were apparently entirely independent of the oxygen administration. The data are summarized in Table V.

No evidence was obtained, therefore, with these methods of study to indicate that the administration of high concentrations of oxygen to patients with sickle cell anemia influences the rate at which red blood cells are destroyed.

\section{Changes in erythrocytogenesis produced by oxygen administration}

During each of the 6 periods of oxygen administration, there were evidences of a striking decrease in the rate of erythrocytogenesis. The initial red blood cell counts in all 4 patients varied from 2 to 3 million cells per cu. $\mathrm{mm}$. This anemia was unquestionably a reflection of the rapidity with which red cells were being destroyed. That the bone marrow was stimulated and trying to compensate for the hemolysis was indicated by the facts that (1) a reticulocytosis of 15 to 30 per cent was present in each case and (2) there was a great predominance of normoblasts in the bone marrow preparations studied. The first change observed in the peripheral blood after a subject began breathing pure oxygen was a decline in reticulocytes which began on the fourth or fifth day of oxygen therapy. Within 48 to 72 hours, the reticulocyte percentage had decreased to 2 to 4 and the number of erythrocytes 
TABLE V

Effect of oxygen administration on the icteric index, serum bilirubin, and serum iron

\begin{tabular}{|c|c|c|c|c|c|}
\hline \multirow{2}{*}{ Patient } & \multirow{2}{*}{ Date } & \multirow{2}{*}{$\begin{array}{l}\text { Icterus } \\
\text { index }\end{array}$} & \multicolumn{2}{|c|}{ Serum bilirubin } & \multirow{2}{*}{$\underset{\text { Serum }}{\text { iron }}$} \\
\hline & & & Direct & Indirect & \\
\hline B. W. & \begin{tabular}{|r|}
$12 / 29 / 41$ \\
$12 / 30 / 41$ \\
$1 / 5 / 42$ \\
$1 / 7 / 42$ \\
$1 / 7 / 42$ \\
$1 / 11 / 42$
\end{tabular} & & $\begin{array}{c}\underset{\text { mgm. }}{\text { per cent }} \\
0.84 \\
\text { oxygen } \\
0.63 \\
\text { oxygen }\end{array}$ & $\begin{array}{c}\text { mgm. } \\
\text { per cent } \\
2.42 \\
\text { started } \\
1.54 \\
1.24 \\
\text { topped } \\
1.34\end{array}$ & $\underset{\text { per cent }}{\operatorname{mgm}}$ \\
\hline L. McC. & $\begin{array}{l}3 / 10 / 42 \\
3 / 14 / 42 \\
3 / 18 / 42 \\
3 / 23 / 42 \\
3 / 26 / 42 \\
3 / 30 / 42 \\
4 / 2 / 42 \\
4 / 8 / 42 \\
4 / 20 / 42 \\
4 / 27 / 42 \\
4 / 27 / 42 \\
5 / 1 / 42 \\
5 / 5 / 42 \\
5 / 9 / 42\end{array}$ & $\begin{array}{r}6 \\
7 \\
13 \\
15 \\
25 \\
30 \\
20 \\
\\
13\end{array}$ & $\begin{array}{c}1.32 \\
0.24 \\
\text { oxygen } \\
0.42 \\
0.63 \\
\text { oxygen } \\
0.63 \\
0.94 \\
0.73 \\
0.70 \\
\text { oxygen } \\
\text { o.61 } \\
\text { oxygen }\end{array}$ & $\begin{array}{c}1.67 \\
0.43 \\
\text { started } \\
0.79 \\
1.38 \\
\text { topped } \\
1.40 \\
1.68 \\
2.17 \\
1.77 \\
\text { started } \\
\\
1.10 \\
\text { topped }\end{array}$ & $\begin{array}{l}0.102 \\
0.041 \\
\\
0.092 \\
0.177 \\
\\
0.215 \\
0.170 \\
0.201 \\
0.101 \\
\\
0.064\end{array}$ \\
\hline B. W. & $\begin{array}{l}7 / 6 / 42 \\
7 / 10 / 42 \\
7 / 10 / 42 \\
7 / 14 / 42 \\
7 / 18 / 42 \\
7 / 23 / 42 \\
7 / 27 / 42 \\
7 / 30 / 42 \\
7 / 30 / 42 \\
8 / 4 / 42 \\
8 / 7 / 42 \\
8 / 14 / 42\end{array}$ & $\begin{array}{r}10 \\
10 \\
15 \\
7 \\
5 \\
5 \\
16 \\
7 \\
10 \\
5\end{array}$ & $\begin{array}{c}0.61 \\
\\
\text { oxygen } \\
0.82 \\
0.68 \\
0.75\end{array}$ & $\begin{array}{c}1.13 \\
\\
\text { topped } \\
1.90 \\
1.44 \\
1.78\end{array}$ & $\begin{array}{l}0.092 \\
0.133 \\
\\
0.071 \\
0.146 \\
0.061 \\
0.097 \\
0.190\end{array}$ \\
\hline
\end{tabular}

had also begun to fall. The drop in number of red blood cells was occasionally as much as one million cells or more. These relationships are graphically illustrated in Figures 2 to 6 . The reticulocytes remained at their low levels as long as oxygen administration was continued except in one patient during a period which lasted for 20 days (Figure 4 ). During the last 10 days of this period, the patient complained bitterly about the discomfort caused by her mask and was found repeatedly with the mask removed. Her reticulocyte count began to rise on the fifteenth day and reached a level of 17 per cent at the time oxygen was stopped. No change occurred in the percentage of reticulocytes during the other 5 periods until about 48 hours after oxygen was discontinued. The reticulocyte level then began to rise rapidly, reached a peak on the seventh or eighth day, remained elevated for 5 to 12 days, and then fell to approximately the pre-oxygen level. The post-oxygen peak reticulocyte values were surprisingly high and varied from 53 to 82 per cent. Shortly after the reticulocyte percentage began to rise, the red blood cells, hemoglobin, and hematocrit levels also started to increase. Within several weeks, their initial values had been regained, and in several instances had even become higher than the pre-oxygen levels.

Coincident with the reticulocytosis which followed the cessation of oxygen therapy, a shower of nucleated red blood cells also appeared in the peripheral blood. Each one of the 4 patients showed an occasional normoblast in the blood under basal conditions, but the number increased sharply on the third day after oxygen, reached a peak on the sixth or seventh day, and then fell to "basal" levels within 3 or four more days. In one instance (Figure 5), when this development was most marked, 2.1 per cent of all the red blood cells in the peripheral circulation were normoblasts.

The progression of changes brought about by the oxygen administration (fall in reticulocytes followed by a decrease in erythrocytes and hemoglobin) was interpreted as evidence of a striking inhibition of erythrocytogenesis. It is suggested that this result is the physiological antithesis of the stimulation of red cell formation which occurs at low oxygen tensions. This interpretation is supported by the tremendous increase in erythrocytogenesis which followed cessation of oxygen administration with consequent lowering of alveolar and arterial oxygen tensions. It is believed that the one subject who developed an increase in reticulocytes while she was still breathing oxygen did so because she removed her mask often enough to lower her alveolar oxygen content, and partially release her marrow from the inhibition of the high oxygen tensions. An alternative explanation might be that her bone marrow became acclimated to the high oxygen tension and began to "escape" the inhibitory effect. In animal experiments, it has been found that, with long continued residence in 95 per cent oxygen chambers, the depression of bone marrow may or may not be continuous; if not, the reticulocytes increase (21). 
G. Colored \%; Age 18 years.

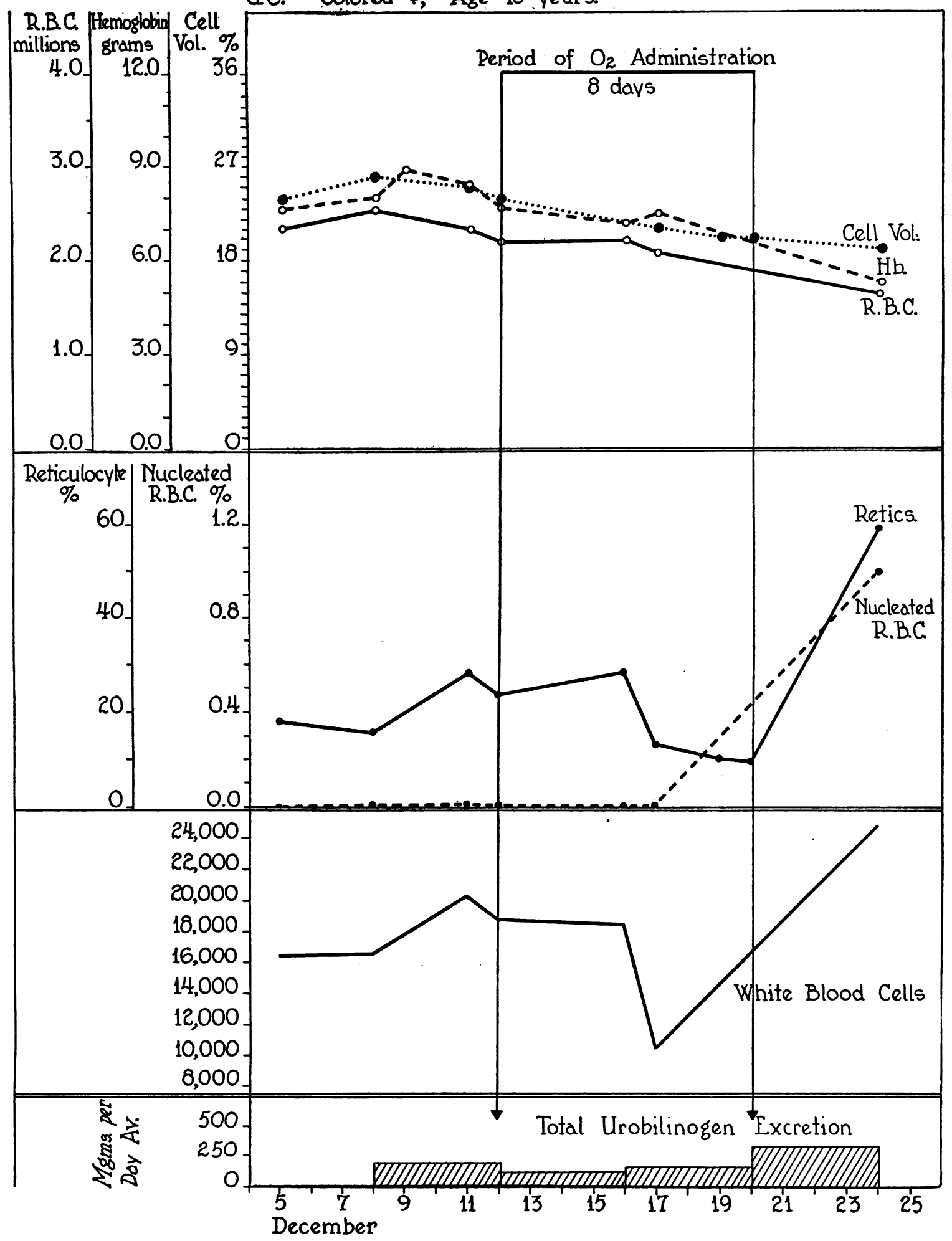

Fig. 2. Effect of Administering Pure Oxygen (B.L.B. Mask) on the Erythroid Equilibrium of a Patient with Sickie Cell ANemia 
B.W. Colored \&. Age 20 years.

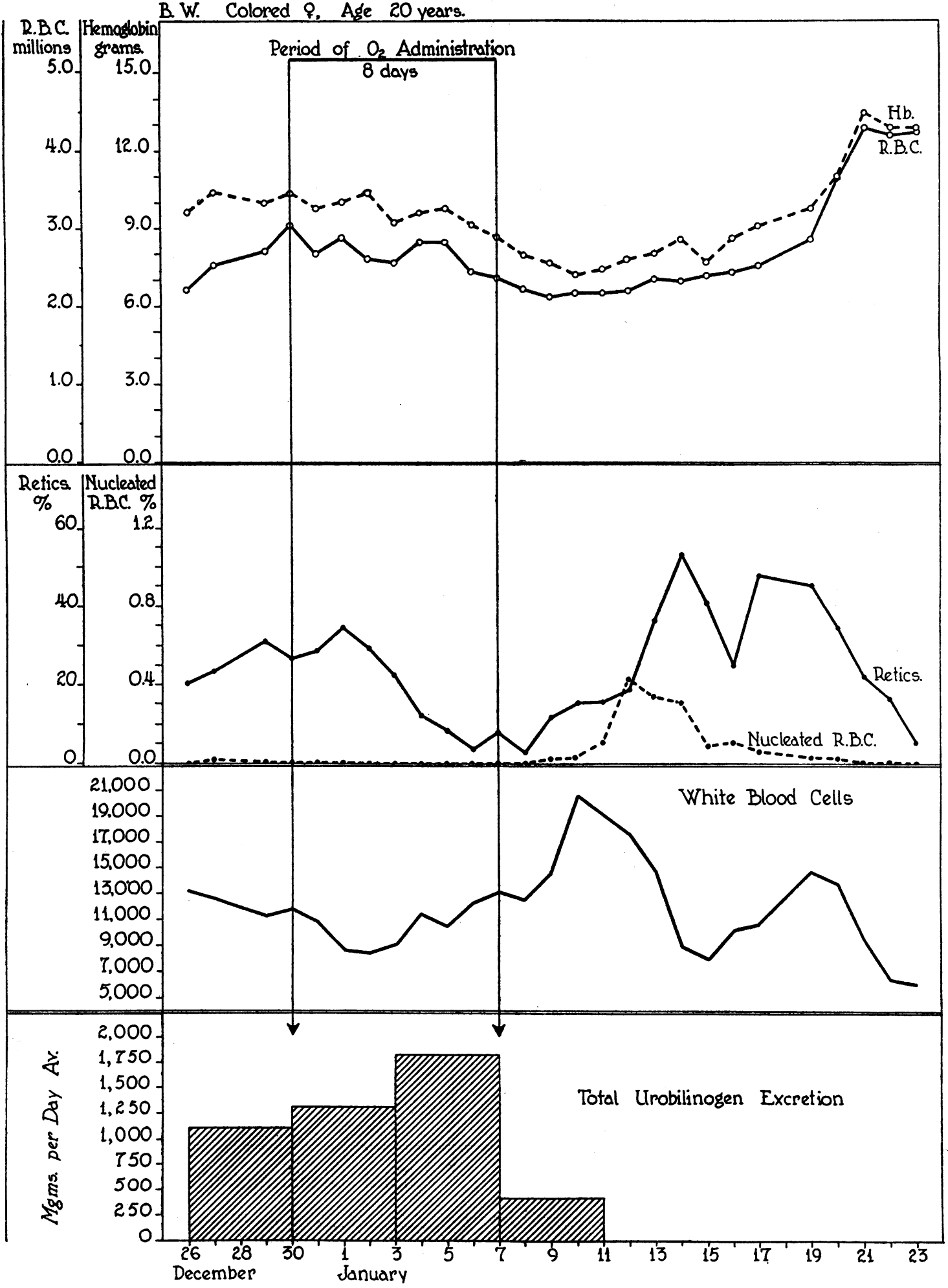

Fig. 3. Effect of Administering Pure Oxygen (B.L.B.Mask) on the Erythroid Equilibrium of a Patient with Sickle Cell Anemia 


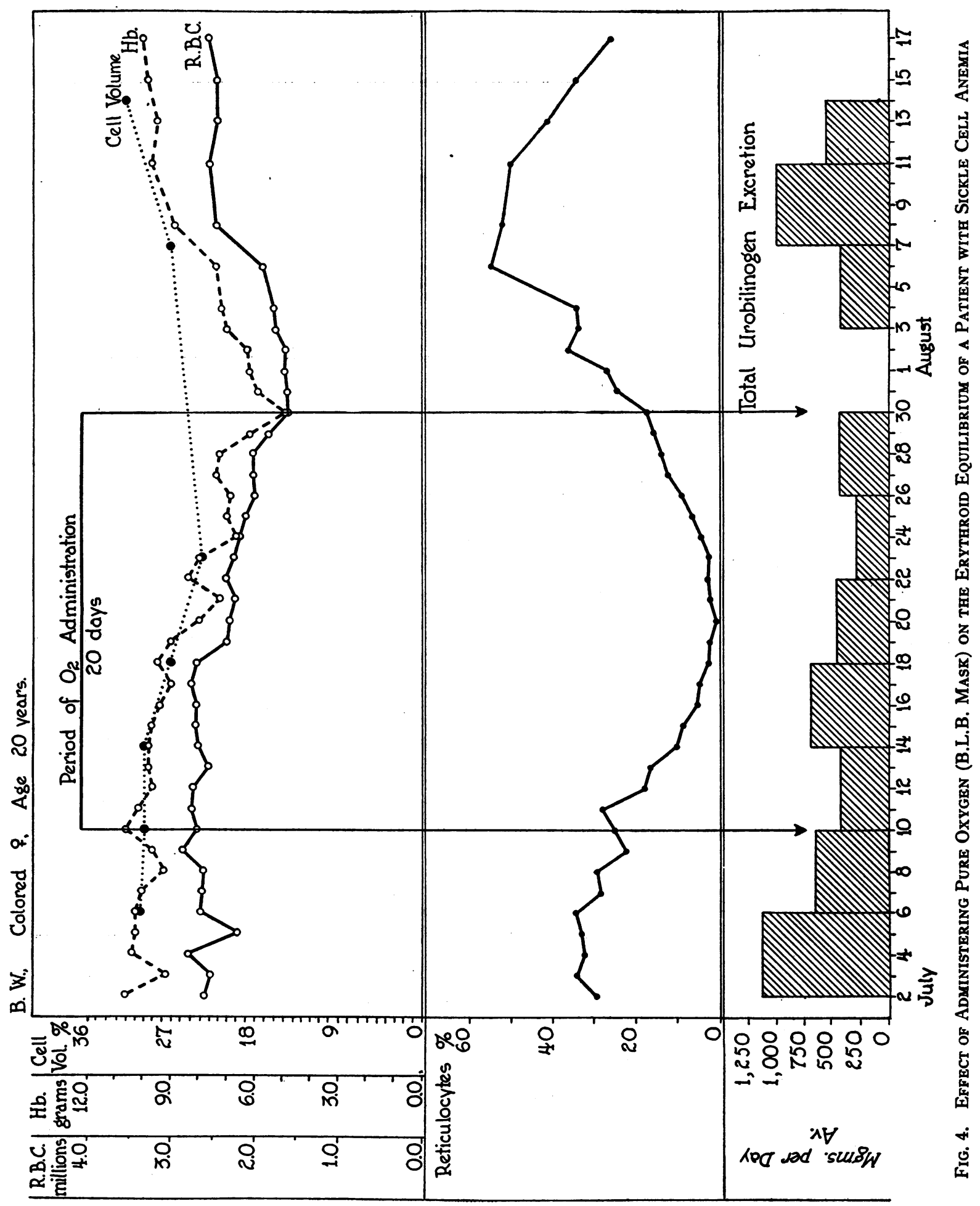




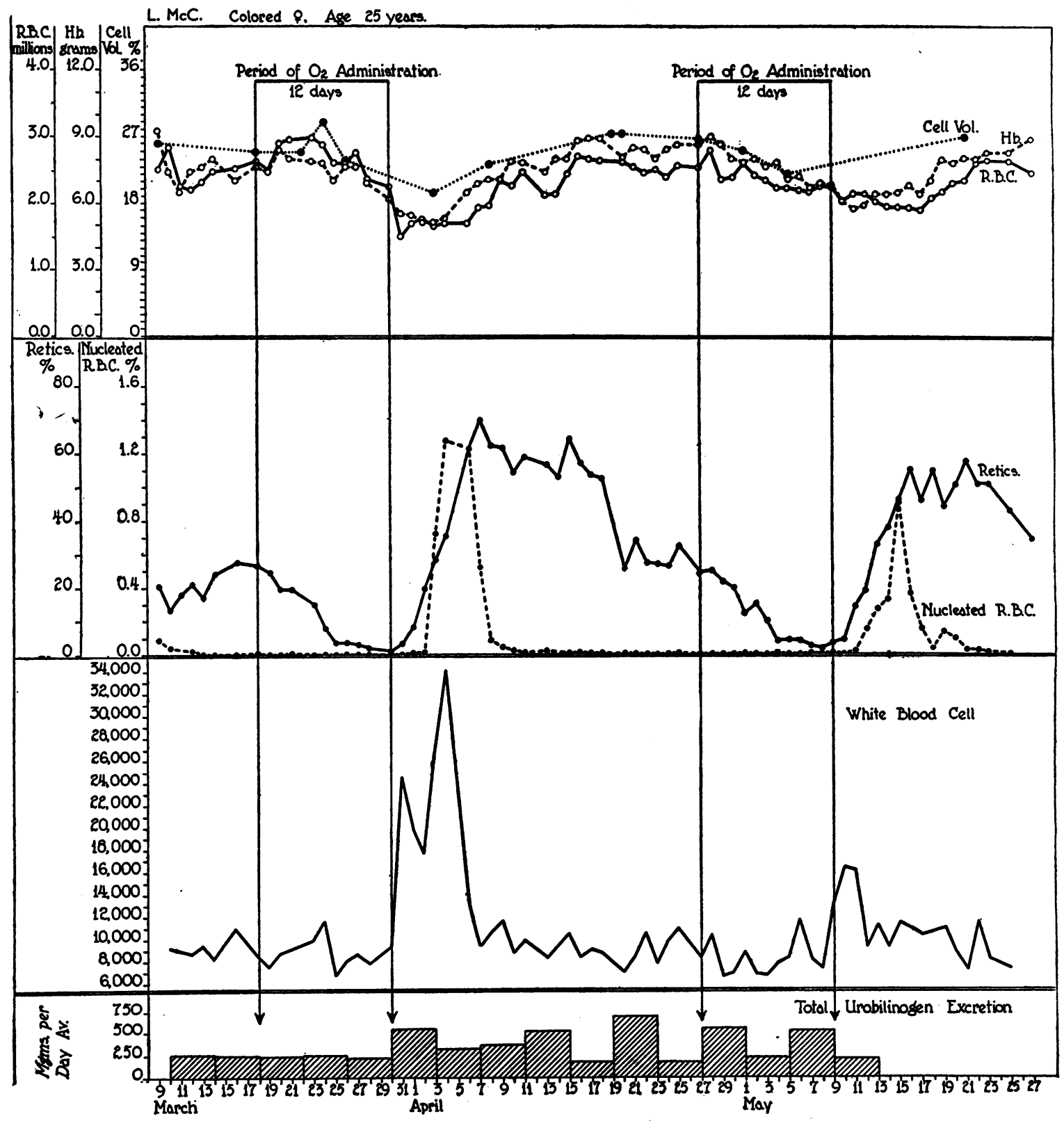

Fig. 5. Effect of Administering Pure Oxygen (B.L.B. Mask) on the Erythroid Equilibrium of a Patient with Sickie Cell Anemia 
T.S. Colored \&, Age 21 years.

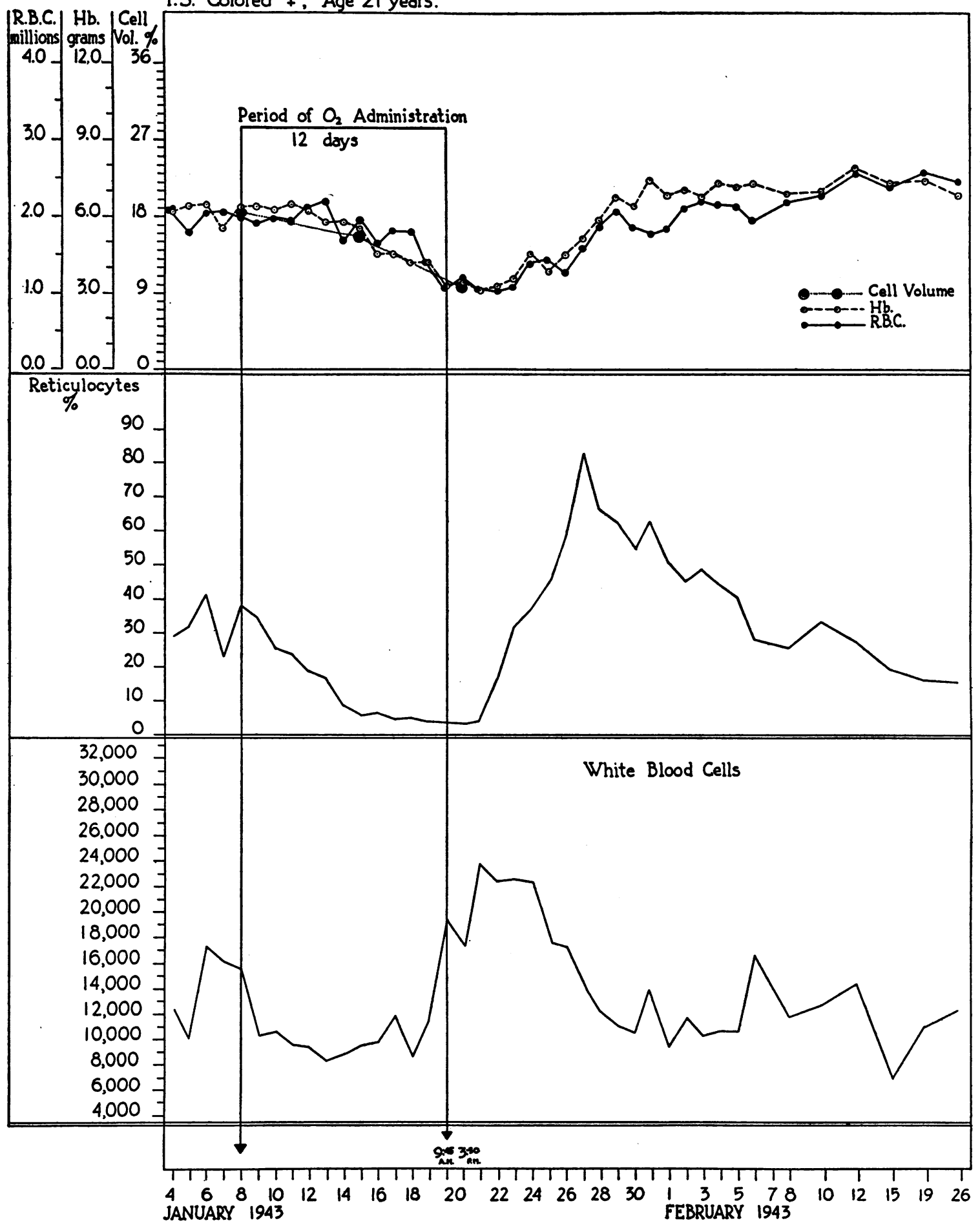

FIG. 6 


\section{Changes in the leukocytes and platelets produced by oxygen administration}

Total white blood cell counts, corrected for the nucleated red cells present, did not change significantly during the periods of oxygen inhalation. In every instance, however, a significant increase in the number of leukocytes developed within 24 to 48 hours after oxygen was discontinued and lasted for a period of 4 to 5 days. This leukocytosis was caused primarily by an absolute increase of mature polymorphonuclear neutrophiles. The number of neutrophilic leukocytes was frequently 2 to 3 times as great as it had been during the period of oxygen therapy. Myelocytes, metamyelocytes, and non-segmented neutrophiles also were increased, an occurrence which suggested that the leukocytosis was caused by an outpouring of cells from the bone marrow rather than by a redistribution phenomenon. Basophilic leukocytes, lymphocytes, and monocytes also participated in the leukocytosis but to a lesser degree than did neutrophilic elements.

No significant changes occurred in the platelet counts during or after oxygen administration.

\section{Evidences of the toxicity produced by pure oxygen}

As was stated earlier, the actual concentration of oxygen in the inspired gas mixture varied, in all probability, from about 70 to 100 per cent, depending upon the activity of the subject. Since these concentrations of oxygen have been found to produce "oxygen pneumonia" and pulmonary edema in animals, the patients were examined very frequently and occasional roentgenograms of the chest were made. No objective evidence of pulmonary congestion or inflammation was detected although one patient did develop a cough. On 2 occasions, oxygen inhalation was accompanied by evidences of irritation of the mucous membrane of the upper respiratory tract (nasal congestion, lacrimation, sore throat, and hoarseness), but in both instances, these symptoms disappeared before oxygen administration was discontinued. Epistaxis occurred twice. Three of the 4 subjects developed anorexia; emesis became distressing in one patient and developed in another after the oxygen inhalation had been stopped. Headache was moderately persistent and annoying in 2 subjects. Paresthesias of the hands or feet were present in 2 of the patients, tenderness of calf muscles in one, and sharp shooting pains in the arms and shoulders in another. There were no signs of nervousness or mental instability. Since these manifestations have considerable clinical interest, a detailed statement of the symptoms experienced by each subject is included with the case histories at the end of this paper.

These symptoms are mild as compared with those shown by animals who are exposed to atmospheres high in oxygen. Adams found that guinea pigs died in 4 days from a sterile pneumonia when they were made to breathe 70 to 100 per cent oxygen (22). Barach has reported that pulmonary edema invariably develops in rabbits given oxygen in concentrations of 80 per cent or more (23). Binger also observed pneumonia in dogs, rabbits, and guinea pigs exposed to $\mathbf{8 0}$ per cent oxygen; the first symptoms of respiratory distress appeared in 2 to 5 days (24). Paine, Lynn, and Keys found hyperemia and congestion of the kidneys, liver, and lungs of dogs kept in an atmosphere of greater than 75 per cent oxygen; the lungs showed pulmonary edema in addition to hyperemia. When the oxygen was increased to 95 or 100 per cent, death occurred, on the average, after 39 hours (25). When these workers kept the dogs in oxygen chambers for only a part of each day, however, the animals were able to tolerate a much longer total exposure to the high oxygen atmosphere. Evans quotes Sayers as saying that he subjected rabbits, guinea pigs, and white rats to practically 100 per cent oxygen for 16 hours each day for 50 consecutive days without observing any obvious harmful effects (26).

Other observers, have found, as did we, that the toxic effects of high concentrations of oxygen in the inspired air are usually not so dramatic in man as in animals. Evans administered pure oxygen by face mask to more than 100 cyanotic patients for periods of from 1 to 27 days (26). He states that some patients who had pulmonary edema before oxygen administration was started were greatly benefited by the inhalation of "pure oxygen," as were also patients with acute and chronic bronchitis. Becker-Freyseng and Clamann (27) placed themselves for 65 hours in a 
chamber the air supply of which contained 90 per cent oxygen. After 24 hours, nervous symptoms appeared. They developed formication of the fingers and toes, and paroxysmal tachycardia. One of them had attacks of vomiting after about 60 hours. Severe bronchitis with fever developed in one of the subjects and his vital capacity fell from 4000 to $2700 \mathrm{ml}$. This decrease in vital capacity was interpreted as indicating inflammatory changes in the pulmonary parenchyma. Behnke, Johnson, Poppen, and Motley have also reported nervous and mental symptoms in human subjects who were breathing 96 to 99 per cent oxygen at pressures of $1,2,3$, and 4 atmospheres (28).

\section{Effect of oxygen administration on the pain of sickle cell crisis}

Only one of the patients, G. C., had the severe pain of a sickle cell crisis at the time oxygen inhalation was begun. She had been having pain in both ankles, the left thigh, and the right shoulder for 3 weeks, but these pains had begun to subside on the morning oxygen administration was started. Twelve hours after she began breathing oxygen, she became free of pain and remained so throughout the 8-day period. Pain reappeared within 24 hours after the B.L.B. mask was removed and became severe 3 days later. This time reinstitution of oxygen therapy did not relieve her symptoms. It seems unlikely that the initial disappearance of pain had any causal relationship to the institution of oxygen therapy, but no general conclusions may be drawn from this one experience.

\section{Discussion}

When high concentrations of oxygen are breathed by patients with sickle cell anemia for 8 to 20 days, the degree of intravascular sickling is decreased, the rate of hemolysis is apparently unaffected, and erythrocytogenesis is depressed. This last observation is the most interesting; it suggests that high tensions of oxygen depress the bone marrow just as low tensions stimulate it. The rôle of oxygen as a principal regulator of red cell regeneration, therefore, is re-emphasized.

Comparatively little attention has been directed in the past to the effect of high oxygen concentrations on bone marrow activity. Bornstein (29) cites experiments by Regnard in which dogs, kept for days in pure oxygen, were found to show a decrease in hemoglobin and red blood cells. Campbell found that a similar decrease in red blood cells and hemoglobin occurred when monkeys, rabbits, rats, guinea pigs, and mice were exposed to 60 per cent oxygen at normal barometric pressure $(30,31)$; cats did not show the change. The blood elements returned to normal after a few weeks exposure to normal oxygen pressure. Boycott and Oakley (21) noted a fall in the number of reticulocytes in rats which were placed in atmospheres providing 50 to 100 per cent oxygen. They interpreted this result as indicating a depression of erythrocytogenesis, but were unable to demonstrate the development of an anemia. Karsner (32) has studied the pathologic effects of atmospheres containing 80 to 96 per cent oxygen administered to rabbits for from 1 to 4 days. He used as controls both rabbits exposed to room air and rabbits exposed to low partial pressures. The experimental animals developed a fibrinous bronchopneumonia in from 24 to 48 hours. Specimens of bone marrow from 10 of these animals showed no distinct departure from the appearance in the controls. The total length of exposure to high oxygen concentrations, however, had been short.

Barach and Richards have also followed the blood counts of 2 human subjects with pulmonary tuberculosis who were kept in an oxygen tent (50 per cent) for 1 to 4 months (33). One of the patients had a red blood cell count of $5,080,000$ and a hemoglobin of 90 per cent at the time oxygen therapy was begun. At the end of 5 weeks in 50 per cent oxygen, his red blood cell count was $5,010,000$, hemoglobin 92 per cent. The second patient had an initial erythrocyte level of $6,340,000$ cells and 121 per cent hemoglobin; these values fell to $5,400,000$ red cells and 95 per cent hemoglobin during oxygen therapy. Barcroft, Hunt, and Dufton studied 26 patients with carbon monoxide poisoning who were placed in oxygen chambers (40 to 50 per cent oxygen) for 16 to 17 hours a day for 5 days (34). In those cases in which the red blood cell count was markedly higher than $5,000,000$ cells, it was reduced to approximately that level during residence in oxygen; the other patients showed no 
change. It will be noted that the only subjects in these 2 investigations who showed any decrease in red blood cells were those who initially had a moderate erythrocytosis, and all of them had complicating factors which tended to interfere with the oxygenation of hemoglobin. The possibility certainly exists in these instances that the moderate erythrocytosis was caused by a relative anoxemia and disappeared when the anoxemia was corrected. These observations, therefore, are not strictly comparable to the ones described in this report. Furthermore, since the concentrations of oxygen used by Barach and Barcroft were relatively low, the failure to demonstrate a clear cut depression of erythrocytogenesis is not surprising.

Patients with a chronic hemolytic anemia, like sickle cell anemia, are exceptionally suitable subjects for this type of investigation. The presence of a relatively high reticulocytosis under "basal" conditions makes it possible to detect early any depression of the rate of red blood cell formation, since the depression would be accompanied by a decrease in the reticulocytes. Furthermore, because of the hemolysis, the erythrocytes have a shorter average life span. The lowered rate of erythrocytogenesis is, consequently, more promptly reflected in the development of an anemia than would be the case under normal circumstances. If similar depression were produced in an individual whose red blood cells are not being destroyed at an abnormally rapid rate, oxygen administration would probably have to be continued for 4 or more weeks before the fall in the red cell count could be detected. This consideration is probably responsible for the failure of Barach and McAlpin (35) and others to lower the erythrocyte levels of patients with polycythemia vera by oxygen administration. Hempelmann, et al. (36) treated 15 patients with polycythemia vera with radioactive phosphorus. The interval from the administration of a single large dose of radioactive phosphorus to the onset of a significant decline in the red blood cells and hemoglobin levels ranged from 33 to 61 days. Hence, in patients with polycythemia vera, well over a month may elapse before a depression of erythrocytogenesis is manifested in the peripheral blood. We have also obtained entirely negative results when high concentrations of oxygen were given for 12 days to a patient with true polycythemia. It is recognized that these observations need to be extended to other hematologic dyscrasias, particularly to other types of hemolytic anemia, before it can be concluded that the changes described are not peculiar to sickle cell anemia.

In order to explain the depressant effect on bone marrow of the high partial pressures of oxygen in alveolar air and in arterial blood, one must assume that these high tensions are transferred, at least in part, to the marrow itself. Since oxygen saturation of both arterial and venous blood was shown to be increased, the bone marrow and all the other tissues of the body must have been exposed to oxygen at a partial pressure somewhat greater than the normal. That this increase in the oxygen tension of the tissues is considerably greater than appears from the increase in the oxygen content of the arterial blood is indicated by the researches of Campbell (37). Campbell found that when rabbits and cats breathed 90.77 per cent oxygen, the oxygen tension of the abdominal cavity rose from a normal level of about $30 \mathrm{~mm}$. $\mathrm{Hg}$ to more than $50 \mathrm{~mm}$. $\mathrm{Hg}$. This relatively large increase develops for 2 reasons: (1) the oxygen tension of tissues is proportional to the oxygen tension of the blood; and (2) the oxygen tension of blood rises rapidly once hemoglobin has become saturated and extra oxygen is physically dissolved in the plasma. When pure oxygen is breathed and hemoglobin has become changed to oxyhemoglobin, more oxygen physically dissolves in plasma until the oxygen tension in the plasma approximates that in the alveoli (Henry's law for the solution of gases in liquids). Consequently, since the oxygen tension in alveoli increases during periods of pure oxygen administration from a normal of about $100 \mathrm{~mm}$. $\mathrm{Hg}$ to over $500 \mathrm{~mm}$. $\mathrm{Hg}$, the small increase in oxygen content of arterial blood over so-called oxygen capacity (physically dissolved oxygen) produces a severalfold increase in oxygen tension of arterial blood. It is because of this relatively high oxygen tension of blood as it enters the arterial end of the capillaries that the normal oxygen tension of tissues is nearly doubled (37). Similar conclusions were reached by Sibree (38). The assumption may be made, therefore, that the oxygen 
tension in the bone marrow was probably raised significantly when the 4 patients used in the present study were given oxygen through a B.L.B. mask. With the increase in oxygen tension, utilization of oxygen may actually be decreased because of toxic effects rather than increased (39).

Reference should be made to the claim of several investigators that plasma volume is slightly increased during periods of intensive oxygen therapy $(28,40)$. Hydremia would cause a slight (relative) lowering of the red blood cell count and hemoglobin values. Simple dilution of the formed elements, however, could not account for a major portion of the changes observed in the patients here reported; the fall in erythrocytes was occasionally as great as $\mathbf{5 0}$ per cent. Furthermore, the alterations in total number of red cells were correlated so closely with other evidences of changes in bone marrow activity that the latter certainly must have been the principal controlling factor.

\section{Summary and conclusions}

During 6 periods of 8 to 20 days each, 4 patients with sickle cell anemia breathed 70 to 100 per cent oxygen administered through a BoothbyLovelace-Bulbulian mask. The following effects were observed:

(1) A decrease in the degree of intravascular sickling of red blood cells occurred.

(2) No consistent detectable change in the rate of hemolysis occurred during the period of oxygen administration.

(3) Erythrocytogenesis was depressed by the oxygen therapy. This depression was reflected in a decrease of both reticulocytes and red blood cells. After oxygen inhalation was discontinued, a striking reticulocytosis developed and the level of erythrocytes returned to the pre-oxygen level. It is suggested that the increased oxygen tension produced in bone marrow by the oxygen administration was responsible for the depression of erythrocytogenesis, and that this effect is the physiological antithesis of the stimulation of red cell formation produced by low oxygen tensions.

(4) Leukocytes and platelets showed no significant numerical or qualitative change. However, after oxygen administration was discon- tinued, an increase in the number of circulating leukocytes, presumably due to an outpouring from the bone marrow, was regularly observed.

(5) Only minor toxic manifestations developed during the periods of oxygen therapy.

\section{Case reports}

G. $C$.

A colored female, 18 years old, had complained for years of recurrent pains in the legs and arms, pain and swelling of the joints, abdominal pain associated at times with nausea and vomiting, and fever. Moderate jaundice had been noticed on 2 occasions. Because of the recurrent joint pain and the presence of a loud apical systolic murmur, several physicians had told her she had rheumatic heart disease. The diagnosis of sickle cell anemia was first made when she was 9 years old. Shortly thereafter, a splenectomy was performed without apparent effect on the symptoms or the degree of anemia. When the present studies on this patient were begun, she had some pain in both thighs but no other symptoms; 2 weeks previously her left ankle had been extremely painful and swollen but this had subsided within 3 or 4 days.

Physical examination revealed a pale young negress with a small ulcer on her left ankle as well as the scar of an old healed ulceration. The sclerae were slightly icteric. The teeth were carious and the breath fetid. The heart was enlarged to percussion, rhythm was regular, and there was a soft blowing systolic murmur heard best at the apex but also audible at the base. The abdomen was negative except for left and right paramedian scars. The left wrist was slightly swollen and painful on motion.

Laboratory data: Red blood cell count was $2,330,000$; hemoglobin 7.6 grams, leukocyte count 16,500 ; reticulocytes 18 per cent. In formalin-fixed venous blood, 53 per cent of the erythrocytes were sickled. The icterus index was 10.

A lateral x-ray of the skull showed a granular appearance of the bones. An electrocardiogram was normal.

Symptoms during oxygen inhalation: 12 hours after oxygen was started, the pain in her left thigh disappeared and did not recur during the period of oxygen inhalation. On the eighth and last day of oxygen inhalation, she developed a sore throat. The following day her temperature rose to $102^{\circ} \mathrm{F}$. That evening her left thigh began to ache again. The sore throat and fever lasted only 3 days but pains grew progressively worse and 4 days after oxygen was stopped, she had very severe pains in both legs and in her back. These gradually subsided over a period of 4 to 5 days.

L. $M C C$.

A colored female, 25 years of age, had been admitted to Barnes Hospital 7 times between March, 1939, and March, 1942. All of the oxygen studies were done during her last admission which was for a period of 9 weeks. At various times, she had had abdominal cramps, pain in the extremities, pain under the sternum, and fever. In 1939, 
delivery of a premature infant was followed by post-partum bleeding. This finally ceased 3 months later following currettage. During the latter months of her pregnancy, an incorrect diagnosis of rheumatic heart disease with mitral stenosis was made. The patient had had pain in the back many times, and, during one of her hospital admissions, she remained in the opisthotonic position screaming with agony for several days. It was necessary to administer avertin by rectum to relieve the muscle spasm and pain. When admitted to Barnes Hospital in March, 1942, for oxygen studies, she had pain in the back and legs, but by the time oxygen administration was actually started she had been entirely asymptomatic for 4 days. Furthermore, she had no symptoms referable to her sickle cell anemia in the interval between the first and second periods of oxygen administration.

Physical examination: The patient was a thin but well developed young negro girl. The skin was clear, the mucous membranes pale. Fundi normal. The heart was moderately enlarged and a blowing systolic murmur was heard over the whole precordium, loudest at the apex. The lungs were clear. Spleen was not palpable.

Laboratory data: Red blood cell count was $3,330,000$, hemoglobin 9.3 grams, white blood cell count 19,500, reticulocyte count 21.6 per cent, platelets 980,000 . The leukocyte differential was normal. Formalin-fixed venous blood contained 47.1 per cent sickled erythrocytes. The urine was normal, and the Kahn reaction was negative. The icterus index was 6 .

Lateral x-ray films of the skull showed a granular appearance of the frontal and parietal bones. The electrocardiogram was normal.

Symptoms during oxygen inhalation: 3 days after oxygen was started, a peculiar numbness and stiffness of both hands were noted. Twenty-four hours later the patient complained of tiny sharp shooting pains in her abdomen, shoulders, and extremities. These differed from any pains she had had in the past in that they lasted only a fraction of a second. The morning of the fifth day of oxygen inhalation she had sharp shooting pains across the whole anterior aspect of her chest. That afternoon she had a headache and the next day this was very intense. Her hands continued to feel numb and her right shoulder became similarly affected. She stated she had never experienced any comparable sensation in the past. All of these symptoms except the numbness of the hands disappeared, and during the last 3 days of oxygen, she felt well except for a feeling of exhaustion. Her appetite fell off progressively and during the 12 days she wore the B.L.B. mask she lost 8 pounds in weight. During the second oxygen period, this one also lasting 12 days, she developed no symptoms except stuffiness of the nose on the second day and headache on the eighth day. In neither case was the discontinuance of oxygen associated with any notable symptoms.

T. S.

A colored female, 21 years of age, at the age of 9 , had had fever with pain and swelling of her ankles, knees, and elbows. These symptoms lasted 3 weeks and the diagnosis of acute rheumatic fever was made. At the age of 16, she developed abdominal pain and pains in her arms, legs, and back. The joints were not swollen. At about the same time, ulcers appeared on both lower legs. The pains gradually disappeared but have recurred at intervals since then. As soon as the leg ulcers healed, new ones appeared. She has had frequent sore throats for the last 4 years.

Physical examination: The patient was pale, thin, and underdeveloped. On ophthalmoscopic examination, the vessels of the fundi were dilated and tortuous. The tonsils were large and chronically inflamed. The heart was not enlarged. A blowing systolic murmur was heard over the whole precordium, loudest at the apex. There were no signs of valvular disease. The spleen was not palpable. Small ulcers were present on the medial aspect of both legs just above the internal malleoli.

Laboratory data: Erythrocyte count was 1,840,000, hemoglobin 6.4 grams, white blood cell count 10,150, reticulocyte percentage 32.6 , platelets 960,000 , leukocyte differential normal. Urine was normal. Kahn negative. In formalin-fixed venous blood, 51 per cent of the erythrocytes were sickled.

Lateral and antero-posterior $x$-rays of the skull were normal as were films of all the long bones of all 4 extremities. An electrocardiogram was normal except for an inverted $\mathrm{T}$-wave in lead CF-4.

Symptoms during oxygen inhalation: No symptoms other than weakness were present when oxygen inhalation was begun. Within 48 hours, anorexia developed. By the third day, the patient was nauseated. Nausea became worse until the twelfth day when she began to vomit. She complained of a very bad taste in her mouth.

On the third day, dizziness and light-headedness appeared. Three days later, she had a slight headache. This increased until by the ninth day her headache was intense. She began to complain of numbness and tingling of the hands and feet on the fifth day. By the ninth day, the hands and feet felt stiff and her calf muscles were sore.

She began to cough on the tenth day and the following day brought up thick mucoid sputum. The mucous membranes of the nose and throat appeared very pale; the lungs were clear to both physical and x-ray examination.

By the morning of the thirteenth day, oxygen administration had to be discontinued because of the intensity of her headache and the constant vomiting. Her cough had improved somewhat but she was still clearing much phlegm from the back of her throat.

After oxygen inhalation was stopped, the patient's nausea and anorexia began to subside within 3 days and by the fifth day were no longer present. The headache, however, persisted for a full week. She had several nosebleeds and a transient sore throat without visible inflammation during the first few post-oxygen days.

B. $W$.

This colored female was 20 years old. When first seen at the Barnes Hospital in September, 1941, this patient gave a history of 10 previous admissions to other hospitals. Her complaints at various times had been abdominal pain with vomiting, pain in the extremities, swelling of the 
legs, pain and swelling of various joints, and fever. On all her hospital admissions, a systolic murmur had been heard at the apex and, on several occasions, the incorrect diagnosis of rheumatic fever and rheumatic heart disease had been made. When oxygen administration was started the first time, the patient had no symptoms, but one week previously she had had an attack of pain without swelling of the right knee. When she was again hospitalized, 7 months later, for a repetition of the oxygen studies, she had just recovered from an attack of severe pain in both legs and mild pain in the shoulders.

Physical examination: Patient was slight of build, rather thin, and pale. The skin was clear. Fundi appeared normal. There was slight icterus of the sclerae. The heart was not enlarged. A soft blowing systolic murmur was heard over the whole precordium. The lungs were clear. Spleen was not palpable. There was no swelling or deformity of any of the joints. The left leg was larger than the right; the left calf measured $37 \mathrm{~cm}$. in circumference while the right calf measured $31 \mathrm{~cm}$. The 2 legs were equal in length.

It was thought that the enlargement of the left lower extremity was the result of a thrombosis of the left femoral vein.

Laboratory data: Erythrocyte count was 2,210,000, hemoglobin 9.6 grams, white blood cell count 13,200, reticulocytes 20.4 per cent, platelets 670,000 . The differential count was essentially normal. In formalin-fixed venous blood, 37.3 per cent of the erythrocytes were sickled. The urine contained a trace of albumin. The Kahn reaction was negative. The icterus index was 30 .

A lateral $x$-ray of the skull showed a poorly defined rounded area of destruction in one of the parietal bones. An electrocardiogram was entirely normal.

Symptoms during oxygen inhalation: No pains of any sort were present during either period of observation. She was given oxygen the first time for $\mathbf{8}$ days, the second time for 20 days. On the fifth day of the first oxygen period, she developed stuffiness of the nose, post nasal discharge, and a severe headache. The next day she was hoarse and complained of a burning sensation in the nose and throat. Examination revealed only swelling and edema of the mucous membranes without other evidence of inflammation. These symptoms lasted 3 days. Her appetite was poor. The day after oxygen was stopped she again had a headache, and the following day she was bothered by slight epigastric discomfort with nausea and vomiting, but this lasted only one day. She had a mild nosebleed. Four days after oxygen was stopped she felt fine and remained asymptomatic until her discharge several weeks later. Beginning about the eighth day of the second oxygen period, the patient again had stuffiness of the nose, impaired hearing, smarting of the eyes with lacrimation, and hoarseness. There were swelling and edema of the mucous membranes of the nose, throat, and larynx without redness. These symptoms cleared up in about 5 to 6 days in spite of the continuance of oxygen administration. The day after oxygen was stopped she had a headache, profound weakness, and complete anorexia. She vomited repeatedly the following day. Two days later she felt perfectly well and remained asymptomatic thereafter.

\section{BIBLIOGRAPHY}

1. Diggs, L. W., and Ching, R. E., Pathology of sickle cell anemia. South. Med. J., 1934, 27, 839.

2. Bauer, J., Sickle cell disease. Arch. Surg., 1940, 41, 1344.

3. Hahn, E. V., and Gillespie, E. B., Sickle cell anemia. Report of a case greatly improved by splenectomy. Experimental study of sickle cell formation. Arch. Int. Med., 1927, 39, 233.

4. Sherman, I. J., The sickling phenomenon, with special reference to the differentiation of sickle cell anemia from the sickle cell trait. Bull. Johns Hopkins Hosp., 1940, 67, 309.

5. Boothby, W. M., Lovelace, W. R., Jr., and Uihlein, A., The B.L.B. oxygen inhalation apparatus: improvements in design and efficiency by studies on oxygen percentages in alveolar air. Proc. Staff Meet., Mayo Clin., 1940, 15, 194.

6. Behnke, A. R., Shaw, L. A., Shilling, C. W., Thomson, R. M., and Messer, A. C., Studies on the effects of high oxygen pressure. I. Effect of high oxygen pressure upon the $\mathrm{CO}_{2}$ and $\mathrm{O}_{2}$ content, the acidity, and the $\mathrm{CO}_{2}$ combining power of the blood. Am. J. Physiol., 1934, 107, 13.

7. Evelyn, K. A., A stabilized photoelectric colorimeter with light filters. J. Biol. Chem., 1936, 115, 63.

8. Dameshek, W., A method for the simultaneous enumeration of reticulocytes and blood platelets. Arch. Int. Med., 1932, 50, 579.

9. Malloy, H. T., and Evelyn, K. A., The determination of bilirubin with the photoelectric colorimeter. J. Biol. Chem., 1937, 119, 481.

10. Moore, C. V., Minnich, V., and Welch, J., Studies in iron transportation and metabolism. III. The normal fluctuations of serum and "easily split-off" blood iron in individual subjects. J. Clin. Invest., 1939, 18, 543.

11. Watson, C. J., Studies of urobilinogen. I. An improved method for the quantitative estimation of urobilinogen in urine and feces. Am. J. Clin. Path., 1936, 6, 458.

12a. Van Slyke, D. D., and Neill, J. M., The determination of gases in blood and other solutions by vacuum extraction and manometric measurement. J. Biol. Chem., 1924, 61, 523.

b. Peters, J. P., and Van Slyke, D. D., Quantitative Clinical Chemistry. Vol. II. Methods. Williams and Wilkins, Baltimore, 1932, pp. 324-328.

13. Henderson, Y., and Morriss, W. H., Applications of gas analysis. I. The determination of $\mathrm{CO}_{2}$ in alveolar air and blood; and the $\mathrm{CO}_{2}$ combining powers of plasma and whole blood. J. Biol. Chem., 1917, 31, 217.

14. Van Slyke, D. D., and Sendroy, J., Jr., Manometric analysis of gas mixtures. I. The determination by simple absorption of carbon dioxide, oxygen, and 
nitrogen in mixtures of these gases. J. Biol. Chem., $1932,95,509$.

15. Haldane, J. S., Respiration. Yale University Press, New Haven, 1927, p. 20.

16. Boothby, W. M., Oxygen administration. The value of high concentration of oxygen for therapy. Proc. Staff Meet., Mayo Clin., 1938, 13, 641.

17. Diggs, L. W., and Bibb, J., The erythrocyte in sickle cell anemia. J. A. M. A., 1939, 112, 695.

18. Klinefelter, H. F., The heart in sickle cell anemia. Am. J. M. Sc., 1942, 203, 34.

19. Moore, C. V., Doan, C. A., and Arrowsmith, W. R., Studies in iron transportation and metabolism. II. Mechanism of iron transportation: its significance in iron utilization in anemic states of varied etiology. J. Clin. Invest., 1937, 16, 627.

20. Watson, C. J., The pyrrol pigments, with particular reference to normal and pathologic hemoglobin metabolism. Downey, H., Handbook of Hematology. Paul B. Hoeber, Inc., New York, 1938, Vol. 4, p. 2447.

21. Boycott, A. E., and Oakley, C. L., The regulation of marrow activity: experiments on blood transfusion and on the influence of atmospheres rich in oxygen. J. Path. and Bact., 1933, 36, 205.

22. Adams, A., The effects of atmospheres enriched with oxygen upon living organisms. Biochem. J., 1912, 6, 297.

23. Barach, A. L., The effects of atmospheres rich in oxygen on normal rabbits and on rabbits with pulmonary tuberculosis. Am. Rev. Tuberculosis, 1926, 13, 293.

24. Binger, C., Faulkner, J. M., and Moore, R., Oxygen poisoning in mammals. J. Exper. Med., 1927, 45, 849.

25. Paine, J. R., Lynn, D., and Keys, A., Observations on the effects of the prolonged administration of high oxygen concentration to dogs. J. Thoracic Surg., 1941, 11, 151.

26. Evans, J. H., The inhalation of pure oxygen in the treatment of disease. Canad. M. A. J., 1930, 22, 518.
27. Becker-Freyseng, H., and Clamann, H. G., Zur Frage der Sauerstoffvergiftung. Klin. Wchnschr., 1939, 18, 1382.

28. Behnke, A. R., Johnson, F. S., Poppen, J. R., and Motley, E. P., The effect of oxygen on man at pressures from 1 to 4 atmospheres. Am. J. Physiol., 1935, 110, 565.

29. Bornstein, A., Ueber den Einfluss der komprimierten Luft auf die Blutbildung. Pflueger's Archiv. für Physiologie, 1911, 138, 609.

30. Campbell, J. A., Prolonged alterations of oxygen pressure in the inspired air with special reference to tissue oxygen tension, tissue carbon dioxide tension, and hemoglobin. J. Physiol., 1927, 62, 211.

31. Campbell, J. A., Further observations on oxygen acclimatisation. J. Physiol., 1927, 63, 325.

32. Karsner, H., The pathological effects of atmospheres rich in oxygen. J. Exper. Med., 1916, 23, 149.

33. Barach, A. L., and Richards, D. W. Jr., Oxygen therapy in pulmonary tuberculosis. Am. Rev. Tuberc., 1932, 26, 241.

34. Barcroft, J., Hunt, G. H., and Dufton, D., The treatment of chronic cases of gas poisoning by continuous oxygen administration in chambers. Quart. J. Med., 1920, 13, 179.

35. Barach, A. L., and McAlpin, K. R., Negative results of oxygen therapy in polycythemia vera. Am. J. M. Sc., 1933, 185, 178.

36. Hempelmann, L. A., Reinhard, E. H., Moore, C. V., and Bierbaum, O. S., Personal observations. To be published.

37a. Campbell, J. A., The influence of oxygen tension in the inspired air upon the oxygen tension of tissues. J. Physiol., 1925, 60, 20.

b. Idem., Gas tensions in tissues. Physiol. Rev., 1931, $11,1$.

38. Sibree, E. W., Gas tensions in the tissues. M. J. Australia, 1940, 1, 429.

39. Stadie, W. C., Riggs, B. C., and Haugaard, N., Oxygen poisoning. Am. J. M. Sc., 1944, 207, pp. 93-95.

40. Anthony, A. J., Utber Sauerstoffatmung. Deutsch. med. Wchnschr., 1940, 66, 482. 